\title{
Front Matter: Volume 7453
}

, "Front Matter: Volume 7453," Proc. SPIE 7453, Infrared Spaceborne Remote Sensing and Instrumentation XVII, 745301 (1 October 2009); doi: $10.1117 / 12.845529$

EDIE Event: SPIE Optical Engineering + Applications, 2009, San Diego, California, SPIE. United States 


\title{
PROCEEDINGS OF SPIE
}

\section{Infrared Spaceborne Remote Sensing and Instrumentation XVII}

\author{
Marija Strojnik \\ Editor
}

5-6 August 2009

San Diego, California, United States

Sponsored and Published by

SPIE

Volume 7453 
The papers included in this volume were part of the technical conference cited on the cover and title page. Papers were selected and subject to review by the editors and conference program committee. Some conference presentations may not be available for publication. The papers published in these proceedings reflect the work and thoughts of the authors and are published herein as submitted. The publisher is not responsible for the validity of the information or for any outcomes resulting from reliance thereon.

Please use the following format to cite material from this book:

Author(s), "Title of Paper," in Infrared Spaceborne Remote Sensing and Instrumentation XVII, edited by Marija Strojnik, Proceedings of SPIE Vol. 7453 (SPIE, Bellingham, WA, 2009) Article CID Number.

ISSN 0277-786X

ISBN 9780819477439

Published by

SPIE

P.O. Box 10, Bellingham, Washington 98227-0010 USA

Telephone +1 3606763290 (Pacific Time) · Fax +1 3606471445

SPIE.org

Copyright (C) 2009, Society of Photo-Optical Instrumentation Engineers

Copying of material in this book for internal or personal use, or for the internal or personal use of specific clients, beyond the fair use provisions granted by the U.S. Copyright Law is authorized by SPIE subject to payment of copying fees. The Transactional Reporting Service base fee for this volume is $\$ 18.00$ per article (or portion thereof), which should be paid directly to the Copyright Clearance Center (CCC), 222 Rosewood Drive, Danvers, MA 01923. Payment may also be made electronically through CCC Online at copyright.com. Other copying for republication, resale, advertising or promotion, or any form of systematic or multiple reproduction of any material in this book is prohibited except with permission in writing from the publisher. The CCC fee code is 0277-786X/09/\$18.00.

Printed in the United States of America.

Publication of record for individual papers is online in the SPIE Digital Library.

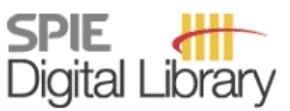

SPIEDigitalLibrary.org

Paper Numbering: Proceedings of SPIE follow an e-First publication model, with papers published first online and then in print and on CD-ROM. Papers are published as they are submitted and meet publication criteria. A unique, consistent, permanent citation identifier (CID) number is assigned to each article at the time of the first publication. Utilization of CIDs allows articles to be fully citable as soon they are published online, and connects the same identifier to all online, print, and electronic versions of the publication. SPIE uses a six-digit CID article numbering system in which:

- The first four digits correspond to the SPIE volume number.

- The last two digits indicate publication order within the volume using a Base 36 numbering system employing both numerals and letters. These two-number sets start with $00,01,02,03,04$, $05,06,07,08,09,0 A, 0 B \ldots 0 Z$, followed by 10-1Z, 20-2Z, etc.

The CID number appears on each page of the manuscript. The complete citation is used on the first page, and an abbreviated version on subsequent pages. Numbers in the index correspond to the last two digits of the six-digit CID number. 


\section{Contents}

vii Conference Committee
ix Introduction

SESSION 1 IR MISSIONS LOOKING INTO SPACE

745302 Stratospheric Observatory for Infrared Astronomy (SOFIA) (Invited Paper) [7453-01]

E. E. Becklin, NASA Ames Research Ctr. (United States); R. D. Gehrz, Univ. of Minnesota (United States)

745303 On sky testing of the SOFIA telescope in preparation for the first science observations (Invited Paper) [7453-02]

F. Harms, J. Wolf, Univ. Stuttgart (Germany) and NASA Ames Research Ctr. (United States); P. Waddell, NASA Ames Research Ctr. (United States) and Universities Space Research Association (United States); E. Dunham, Lowell Observatory (United States); A. Reinacher, U. Lampater, H. Jakob, Univ. Stuttgart (Germany) and NASA Dryden Flight Research Ctr. (United States); L. Bjarke, NASA Ames Research Ctr. (United States) and NASA Dryden Flight Research Ctr. (United States); S. Adams, R. Grashuis, A. Meyer, K. Bower, NASA Ames Research Ctr. (United States) and Universities Space Research Association (United States); K. Schweikhard, NASA Dryden Flight Research Ctr. (United States); T. Keilig, Univ. Stuttgart (Germany) and NASA Dryden Flight Research Ctr. (United States)

745304 The EXIST optical and infra-red telescope (IRT) and imager-spectrometer [7453-03] A. S. Kutyrev, S. H. Moseley, NASA Goddard Space Flight Ctr. (United States); C. Golisano, ITT Corp. (United States); Q. Gong, NASA Goddard Space Flight Ctr. (United States); B. T. Allen, Harvard-Smithsonian Ctr. for Astrophysics (United States); N. Gehrels, NASA Goddard Space Flight Ctr. (United States); J. E. Grindlay, J. S. Hong, Harvard-Smithsonian Ctr. for Astrophysics (United States); B. E. Woodgate, NASA Goddard Space Flight Ctr. (United States)

\section{SESSION 2 IR MISSIONS LOOKING DOWN}

745305 Thermal infrared imaging of Mercury: MERTIS-a new remote sensing technology [7453-06] G. E. Arnold, Westfaelische Wilhelms Univ. (Germany) and Deutsches Zentrum für Luft- und Raumfahrt e.V. (Germany); H. Hiesinger, Westfaelische Wilhelms Univ. (Germany); J. Helbert, C. Paproth, T. Säuberlich, G. Peter, I. Walter, Deutsches Zentrum für Luft- und Raumfahrt e.V. (Germany)

745306 MERTIS: background signal removal and signal simulation [7453-07]

T. Säuberlich, C. Paproth, J. Helbert, Deutsches Zentrum für Luft- und Raumfahrt e.V. (Germany); H. Hiesinger, Westfaelische Wilhelms Univ. (Germany)

$745307 \quad$ MISTIGRI: instrumental concept for high-resolution thermal infrared imaging [7453-08] F. Tintó Garcia-Moreno, Ctr. National d'Études Spatiales (France); G. Fargant, F. Guerin, C. Israbian, J. C. Mathieu, Thales Alenia Space (France); J. Michaud, A. Bardoux, O. Hagolle, Ctr. National d'Études Spatiales (France); J. P. Lagouarde, Institut National de la Recherche Agronomique (France) 
745308 Performances of the SAC-D NIRST flight model radiometer [7453-09]

M. R. Leclerc, L. Marchese, P. Côté, F. Châteauneuf, C. Chevalier, INO (Canada);

H. Marraco, Comisión Nacional de Actividades Espaciales (Argentina); L. Ngo Phong,

Canadian Space Agency (Canada)

\section{SESSION $3 \quad$ IR MISSIONS LOOKING AT THE ATMOSPHERE}

7453 OC Meteosat Third Generation (MTG): mission and system concepts [7453-13]

A. Rodriguez, R. Stuhlmann, S. Tjemkes, European Organisation for the Exploitation of Meteorological Satellites (Germany); D. M. Aminou, H. Stark, P. Blythe, European Space Agency (Netherlands)

7453 OD The evolution of the performance of the AVHRR, HIRS, and AMSU-A instruments onboard MetOp-A after over two years in orbit [7453-14]

D. Battles, Raytheon Technical Services Co. (Germany); A. Pérez Albiñana, European Space Agency (Netherlands); R. W. Lambeck, Perot Systems Government Service (United States); F. Montagner, European Organisation for the Exploitation of Meteorological Satellites (Germany); H. Bauch, VEGA Deutschland GmbH (Germany); R. Alemán, NASA Goddard Space Flight Ctr. (United States); C. Jackson, National Oceanic and Atmospheric Administration (United States)

\section{SESSION $4 \quad$ IR TECHNOLOGIES}

7453 OF Improved determination of surface and atmospheric temperatures using only shortwave AIRS channels (Invited Paper) [7453-16]

J. Susskind, J. Blaisdell, L. Iredell, NASA Goddard Space Flight Ctr. (United States)

7453 OG Improving forecast skill by assimilation of quality controlled AIRS Version 5 temperature soundings [7453-17]

J. Susskind, O. Reale, NASA Goddard Space Flight Ctr. (United States)

$7453 \mathrm{OH}$ The broadband radiometer on the EarthCARE spacecraft [7453-18]

K. Wallace, European Space Agency (Netherlands); N. Wright, D. Spilling, Systems Engineering \& Assessment Ltd. (United Kingdom); K. Ward, M. Caldwell, Rutherford Appleton Lab. (United Kingdom)

7453 Ol Efficient characterization of imaging spectrometers: application in the LWIR and MWIR [7453-19]

T. J. Valle, T. U. Kampe, P. R. Wamsley, H. Chase, G. E. Taudien, P. T. Spuhler, P. B. Johnson, G. L. Mills, Ball Aerospace \& Technologies Corp. (United States)

7453 OJ Photoconductive response of PbSnTe(In) in the terahertz spectral range [7453-20] D. Khokhlov, A. Galeeva, D. Dolzhenko, L. Ryabova, M.V. Lomonosov Moscow State Univ. (Russian Federation); A. Nicorici, Institute of Applied Physics (Moldova); S. Ganichev, S. Danilov, Univ. of Regensburg (Germany); V. Bel'kov, Univ. of Regensburg (Germany) and A.F. Ioffe Physical-Technical Institute (Russian Federation) 
7453 OK A proposed global atmospheric monitoring network based on standard stars (Invited Paper) [7453-21]

J. T. McGraw, P. C. Zimmer, The Univ. of New Mexico (United States); S. W. Brown, G. T. Fraser, K. R. Lykke, A. W. Smith, National Institute of Standards and Technology (United States);

C. W. Stubbs, Harvard Univ. (United States); J. T. Woodward, National Institute of Standards and Technology (United States)

7453 ON Spectral irradiance responsivity calibration of InSb radiometers using the improved IR-SIRCUS at NIST [7453-24]

J. Zeng, National Institute of Standards and Technology (United States) and Utah State Univ. (United States); H. W. Yoon, G. P. Eppeldaver, L. M. Hanssen, J. P. Rice, National Institute of Standards and Technology (United States)

745300 Comparison of several surfaces for use as a MWIR BRDF standard [7453-25]

B. L. Balling, Air Force Research Lab. (United States); M. A. Marciniak, Air Force Institute of Technology (United States)

$74530 Q$ Development of an infrared optical scattering instrument from $1 \mu \mathrm{m}$ to $5 \boldsymbol{\mu m}$ [7453-27] J. Zeng, Utah State Univ. (United States); L. Hanssen, National Institute of Standards and Technology (United States)

\section{SESSION 6 APPLICATIONS OF IR TECHNOLOGIES}

7453 OR IV-VI mid-IR tunable lasers and detectors with external resonant cavities (Invited Paper) [7453-28]

H. Zogg, M. Rahim, A. Khiar, M. Fill, F. Felder, N. Quack, S. Blunier, J. Dual, ETH Zürich (Switzerland)

7453 OS The EarthCARE broadband radiometer detectors [7453-29]

C. Proulx, F. Williamson, M. Allard, G. Baldenberger, D. Gay, S. Garcia-Blanco, P. Côté, L. Martin, C. Larouche, S. llias, T. Pope, Institut National d'Optique (Canada); M. Caldwell, K. Ward, J. Delderfield, Rutherford Appleton Lab. (United Kingdom)

7453 OT Numerical and experimental evaluation of road infrastructure perception in fog and/or night conditions using infrared and photometric vision systems [7453-30]

J. Dumoulin, Lab. Central des Ponts et Chaussées (France); V. Boucher, F. Greffier, Lab. Régional des Ponts et Chaussées d'Angers (France)

\section{POSTER SESSION}

7453 OU A stitching method to test the segments of a large primary [7453-05]

E. Gutierrez-Herrera, M. Strojnik, Ctr. de Investigaciones en Óptica, A.C. (Mexico); P. Shore, P. Morantz, Cranfield Univ. (United Kingdom); G. Paez, Ctr. de Investigaciones en Óptica, A.C. (Mexico)

$7453 \mathrm{OV} \quad$ Transillumination waveform simulator for pulse oximetry [7453-31]

C. Vazquez-Jaccaud, G. Paez, M. Strojnik, Ctr. de Investigaciones en Óptica, A.C. (Mexico) 
7453 OW Noise reduction technique for IR-to-visible radiation conversion based on EuTTA fluorescence properties [7453-32]

M. Alfaro, G. Paez, M. Strojnik, Ctr. de Investigaciones en Óptica, A.C. (Mexico)

7453 0X Analysis of some rotational shearing interferometers to detect extrasolar planets [7453-33] M. Galan, M. Strojnik, G. Paez, Ctr. de Investigaciones en Óptica, A.C. (Mexico)

7453 OY Tissue characterization with ballistic photons [7453-34]

M. Strojnik, G. Paez, Ctr. de Investigaciones en Óptica, A.C. (Mexico)

$74530 Z$ Point-spread function for multiple Bracewell interferometric configurations [7453-35]

M. Strojnik, Ctr. de Investigaciones en Óptica, A.C. (Mexico)

\section{ADDITIONAL PAPER}

745310 Power emitted by a nearby solar system and intercepted by a system of apertures near Earth [7453-36]

M. Strojnik, Ctr. de Investigaciones en Óptica, A.C. (Mexico)

Author Index 


\title{
Conference Committee
}

\author{
Program Track Chair
}

Allen H.-L. Huang, University of Wisconsin, Madison (United States)

Conference Chair

Marija Strojnik, Centro de Investigaciones en Óptica, A.C. (Mexico)

Program Committee

John Antoniades, BAE Systems (United States)

Gail E. Bingham, Utah State University (United States)

David A. Cardimona, Air Force Research Laboratory (United States)

Catherine J. Cesarsky, European Southern Observatory (Germany)

Jam Farhoomand, TechnoScience Corporation (United States)

Gerald T. Fraser, National Institute of Standards and Technology (United States)

John C. Gille, National Center for Atmospheric Research (United States)

Sarath D. Gunapala, Jet Propulsion Laboratory (United States)

Dietrich Lemke, Max-Planck-Institut für Astronomie (Germany)

Gonzalo Paez, Centro de Investigaciones en Óptica, A.C. (Mexico)

Jan L. Williams, e-Systems Management Consultants (United States)

Juergen Wolf, NASA Ames Research Center (United States)

\section{Session Chairs}

$1 \quad$ IR Missions Looking into Space

Eric E. Becklin, NASA Ames Research Center (United States)

2 IR Missions Looking Down

Gonzalo Paez, Centro de Investigaciones en Óptica, A.C. (Mexico)

Marija Strojnik, Centro de Investigaciones en Óptica, A.C. (Mexico)

3 IR Missions Looking at the Atmosphere

John C. Gille, National Center for Atmospheric Research (United

States)

$4 \quad$ IR Technologies

Marija Strojnik, Centro de Investigaciones en Óptica, A.C. (Mexico)

Gonzalo Paez, Centro de Investigaciones en Óptica, A.C. (Mexico) 
$5 \quad$ Radiometric Standards at NIST

John T. Woodward, National Institute of Standards and Technology (United States)

6 Applications of IR Technologies

Sergey N. Mekhontsev, National Institute of Standards and Technology (United States) 


\section{Introduction}

This year, our conference has the number 17 in the sequence of this event. For me, this is a source of great satisfaction. I first joined this SPIE conference on Infrared Technology and Applications as a chair in 1991, having organized a twoday Jet Propulsion Laboratory session. Those were good times for IR and space exploration: the U.S. space IR observational facility was fully funded with a large aperture telescope to compete with the European facility, Infrared Space Observatory, known as ISO, which was nearing deployment.

This year, our conference included six sessions and a poster session: IR Missions Looking into Space, IR Missions Looking Down, IR Missions Looking at the Atmosphere, IR Technologies, Radiometric Standards at NIST, and Applications of IR Technologies. Altogether, 32 papers were presented with authors representing the U.S., most of the western European countries, Russia, Canada, Mexico and Argentina, with about one-third of the papers being written by authors from different countries. The participants felt that the papers were of interest and we are proud of good interactions between the presenters and the audience. Most talks were followed by vivid discussions, and some had to be continued during the break times.

A great deal of the conference success may be attributed to the active participation of the attendees. Another significant contribution goes to the experienced and dexterous committee members who also participated as session chairs. Finally, a tremendous amount of work is performed behind the scenes by SPIE staff who conduct all the organizational tasks that make the conference run so smoothly and who finally publish an outstanding book in such a short time. To all such active players, I wish to express my most profound gratitude, hoping for future collaborations.

Marija Strojnik 
Downloaded From: https://www.spiedigitallibrary.org/conference-proceedings-of-spie on 26 Apr 2023

Terms of Use: https://www.spiedigitallibrary.org/terms-of-use 